This is an Author's Accepted Manuscript of an article published as: LOURENÇO, I.C. and CURTO, D.J. (2010) Determinants of the Accounting Choice between

Alternative Reporting Methods for Interests in Jointly Controlled Entities. European Accounting Review, 19(4), 739-773 [copyright Taylor \& Francis], available online at: http://www.tandfonline.com/ DOI

http://dx.doi.org/10.1080/09638181003687844 


\title{
Determinants of the Accounting Choice between Alternative Reporting Methods for Interests in Jointly Controlled Entities
}

\author{
ISABEL COSTA LOURENÇO and JOSÉ DIAS CURTO \\ ISCTE - IUL Business School, Portugal
}

(Received: September 2008; Accepted November 2009)

\begin{abstract}
This paper examines whether the type of jointly controlled entity influences the management choice to report interests in this kind of joint venture using the equity method or proportionate consolidation. We address this gap in the accounting choice literature by exploiting the UK setting where, due to the transition to IFRS, firms had to change their reporting method for interests in jointly controlled entities from the gross equity method to a similar approach (equity method) or to proportionate consolidation. We support our analysis on the classification of jointly controlled entities proposed by Hennart (1988). We hypothesize that venturers are more likely to change their reporting method to proportionate consolidation when the majority of their jointly controlled entities are cases of Link instead of Scale cooperation. After controlling for several variables, our results are consistent with the predictions and thus suggest that the type of jointly controlled entity plays an important role in the management decision to report interests in jointly controlled entities using the equity method or proportionate consolidation. However, the results also provide empirical evidence supporting the importance of debt covenant costs and monitoring costs in the choice between alternative reporting methods.
\end{abstract}

\section{Introduction}

There is no international consensus on the appropriate reporting method for interests in Jointly Controlled Entities (JCEs). Alternatives include the equity method and proportionate consolidation. Policy makers are conscious of the

Correspondence Address: Isabel Lourenço, ISCTE - IUL Business School, Avenida das Forças Armadas, 1649-026 Lisboa, Portugal. Email: isabel.lourenco@iscte.pt

0963-8180 Print/1468-4497 Online/10/000001-35 C) 2010 European Accounting Association DOI: $10.1080 / 09638181003687844$

Published by Routledge Journals, Taylor \& Francis Ltd on behalf of the EAA. 
need to find a consensual solution on this issue. The IASB engaged in a shortterm convergence project with the FASB in order to achieve convergence by removing the option of accounting for interests in JCEs using either the equity method or proportionate consolidation from IAS 31, Interests in Joint Ventures (2003). The latest tentative decision consists of the elimination of proportionate consolidation.

Previous studies do not support this decision. They provide evidence of the incremental usefulness of proportionate consolidation (e.g. Graham et al., 2003; Stoltzfus and Epps, 2005; Bauman, 2007) or of the usefulness of additional information provided by venturers about their interests in joint ventures (e.g. Lim et al., 2003; Kothavala, 2003; Bauman, 2003; Soonawalla, 2005; O'Hanlon and Taylor, 2007).

These efforts to find international consensus on the appropriate reporting method for interests in JCEs are hampered by a gap in our knowledge on what determines the venturer's accounting choice to report interests in JCEs using the equity method or proportionate consolidation. This paper addresses this gap in the accounting choice literature by exploiting the UK setting where firms had to change their reporting method from the gross equity method (an extension of the equity method) to either the equity method or proportionate consolidation following the mandatory adoption of IFRS in 2005.

This research relies on the extent to which management choices are based on their insights into the underlying economics of their JCEs. More specifically, our research question is whether the type of JCE plays a significant role in the management choice to report interests in JCEs using the equity method or proportionate consolidation. We support our analysis on the classification of JCEs, in Scale and Link, proposed by Hennart (1988). Scale JCEs are created when the venturers belong to the same industry and they enter a contiguous stage of production or distribution or a new market together (homogeneous cooperation). As the venturer's relationship with a Scale JCE is similar to that with a third party with whom it has an arm's-length contract but where the venturer is protected by a guarantee (the common-control over that third-party), the equity method seems to be a more appropriate method for reporting interests in Scale JCEs. On the other hand, Link JCEs are created when the venturers come from different industries to enter a new business together and each contributes in a different way so as to develop the new business (heterogeneous cooperation). As each venturer contributes to the Link JCE by providing distinct critical resources, the venturer's relationship with the Link JCE is unlike the relation with a third party and the proportionate consolidation therefore seems to be a more appropriate method for reporting interests in Link JCEs.

Our hypothesis is that the venturer is more likely to change the reporting method to proportionate consolidation when the majority of its JCEs are cases of Link cooperation. After controlling for several variables, our results are consistent with this prediction. However, the results also provide empirical evidence supporting the importance of debt covenant costs and monitoring costs in the 
choice between the two alternative reporting methods. More specifically, we find that venturers with economic incentives to apply proportionate consolidation (because the majority of their JCEs are Link) are less likely to apply this method when their leverage is lower but approximate to the industry median, when their return on assets is lower than the cost of debt or, finally, when the change to proportionate consolidation instead of the equity method would have a significant impact on the venturer's total assets and total liabilities. In the last case, the change would carry a higher cost for shareholders when analysing the venturers' relative accounting performance measures.

This study contributes to accounting research in several ways. First, we bring new evidence on the extent to which managers exercise their discretion to choose the accounting method based on their insights into the underlying economics of their firms. Few papers consider real influences in accounting choice. They include the LIFO/FIFO inventory model developed by Lindahl (1989), the consolidation studies developed by Whittred ${ }^{1}$ (1987) and by Mian and Smith ${ }^{2}$ (1990), the Whittred and Zimmer ${ }^{3}$ (1994) study on joint ventures and the intangible assets study developed by Wyatt (2005). Second, we provide new evidence on the extent to which the venturer's decision about the reporting method for interests in JCEs is a consequence of the type of JCEs of the venturer. Whittred (1987) has already documented a relationship between the adoption of consolidation reporting and the type of subsidiaries. Mian and Smith (1990) also show that a firm's consolidation decision relies on the type of relationship between the parent and its subsidiaries. We extend these conclusions to the issue of JCEs.

In addition to the contributions referred to above, we also provide empirical evidence supporting the importance of debt covenant cost and monitoring costs in the choice between alternative reporting methods. There is already extensive literature that seeks to explain firms' accounting method choice within the framework of debt covenant costs. In contrast, only a few studies analyse the importance of monitoring costs on the choice between accounting methods (e.g. Knoeber and McKee, 1991). We provide evidence on this issue using the UK setting of transition to IFRS, where firms face the possibility of changing to a completely new reporting method that could, in some cases, provide benefits, but at the expense of higher monitoring costs due to the lack of comparability between financial statements. We use the magnitude of the financial statements effects of the decision to change to proportionate consolidation instead of to the equity method as a proxy for the existence of influential monitoring costs. Some previous studies also provide evidence that incentives to choose among alternative accounting methods include the magnitude of the financial statements effects of the choice (e.g. Hand and Skantz, 1998; D'Souza et al., 2001; Jeter et al., 2008). We extend these conclusions to the framework of monitoring costs.

Our research could also provide a useful contribution to the international debate on this issue, including to the IASB's joint convergence project to find a consensual solution and remove the option of accounting for interests in JCEs from IAS 31, Interests in Joint Ventures (IASB, 2003). Our findings 
suggest that requiring all ventures to report interests in JCEs using just one method, the equity method according to the IASB intention, would tend to reduce the reliability of financial statements, namely those presented by the Ventures with Link JCEs. In this case, financial statements would not represent the substance of the JCEs.

The remainder of the paper is organized as follows. Section 2 contrasts the two alternative approaches to reporting interests in JCEs. Section 3 develops the theoretical framework of this study. Section 4 describes the research design and section 5 analyses the research results. Finally, section 6 presents the summary and concluding remarks.

\section{Reporting Methods for Interests in Jointly Controlled Entities}

Different reporting methods for interests in JCEs are required or allowed by different standard setters around the world. On one hand, the equity method is required both by the American APB Opinion 18, The Equity Method of Accounting for Investments in Common Stock (APB, 1971) and by the Australian ASB 131, Interests in Joint Ventures (AASB, 2004). In the United Kingdom, the FRS 9, Associates and Joint Ventures (ASB, 1997), requires venturers to apply the gross equity method, which is an extension of the equity method. On the other hand, the Canadian Institute of Chartered Accountants Handbook, Section 3005, Interests in Joint Ventures (CICA, 1994) requires proportionate consolidation. The IAS 31, Interests in Joint Ventures (IASB, 2003), recommends proportionate consolidation (with two possible reporting formats), in spite of allowing the equity method.

Four different reporting methods for interests in JCEs are thus identified, namely the equity method, the gross equity method and the two formats for proportionate consolidation. These four methods can be aggregated in two alternative approaches, reporting interests in JCEs as an asset (equity method and gross equity method) and reporting interests in JCEs as a set of assets and liabilities (the two formats for proportionate consolidation).

According to the first approach (equity method and gross equity method), the Balance Sheet should report the venturer's share of JCEs' net assets as an asset. The Income Statement should report the venturer's share of JCEs' net income as a financial gain or loss. According to the second approach (the two formats for proportionate consolidation), the Balance Sheet should report the venturer's share of JCEs' assets and liabilities separately as assets and as liabilities, respectively. The Income Statement should report the venturer's share of JCEs' revenue and expenses separately as revenue and as expenses, respectively. ${ }^{4}$

These two alternative approaches to reporting interests in JCEs lead to different amounts being presented in the Balance Sheet, as assets and liabilities, as well as in the Income Statement, as revenue and expenses. If we replace the equity method by proportionate consolidation, both total assets and total liabilities increase by the venturer's share of JCEs' liabilities. ${ }^{5}$ The leverage ratio would 
be higher as a result of this change. Furthermore, both revenue and expenses increase by the venturer's share of JCEs' expenses and the venturer's share of the JCEs' net income is no longer a financial result but an operating result. These changes would have an impact on the return on assets. ${ }^{6}$ Despite theses changes, shareholders equity and net income remain the same as well as the return on shareholders equity.

In the UK, the FRS 9, Associates and Joint Ventures (ASB, 1997) requires venturers to report interests in JCEs by the gross equity method. According to this procedure, interests in JCEs are reported as an asset but additional information about the venturer's share of JCEs' assets, liabilities, revenue and expenses are also presented as desegregations in the face of the Balance Sheet and Income Statement. ${ }^{7}$

Owing to the mandatory transition to IFRS in 2005, listed firms in the UK had to choose between two alternatives: (i) reporting interests in JCEs using the equity method, which means not changing the procedure currently in practice; or (ii) reporting interests in JCEs using proportionate consolidation thus requiring venturers to develop a more complex consolidation procedure that could, moreover, have a negative impact on the financial ratio analysis (e.g. leverage could be significantly higher and return on assets could be significantly lower).

As the IAS 31, Interests in Joint Ventures (IASB, 2003) requires venturers to disclose in the Notes additional information quite similar to that previously provided in the face of financial statements according to UK accounting standards, ${ }^{8}$ the change from the gross equity method to the equity method is a formality whereby the disclosures are now presented in the Notes rather than as desegregations in the face of the Balance Sheet and Income Statement. The change to proportionate consolidation is a real change from a case of disclosure to a case of recognition of the venturer's interest in JCEs' assets, liabilities, revenue and expenses.

Therefore, the choice of proportionate consolidation consists of a change in the status quo. It could carry some significant costs for firms using the equity method for internal control purposes. Otherwise, some benefits for firms that already use proportionate consolidation for internal control purposes are predicted. We expect UK firms to change to proportionate consolidation when this method better reflects the substance and the economic reality of the JCEs and is therefore used for internal control purposes.

As in Mian and Smith (1990), the hypothesis we develop in the next section relies on the presupposition that if a method is more appropriate for internal control purposes, that method will also tend to be used for external reporting. The adoption of different methods for internal and external purposes imposes costs. First, there are potential political costs associated with employing different figures for external reporting and for internal control. Second, the use of internal accounting figures in judging managerial performance and setting compensation provides a demand for their external verification, whereas only one external audit is required when the same figures are used for both internal control and external 
financial reporting. Finally, conditioning contracts on accounting figures employed for a wide variety of purposes controls the incentive to manipulate the numbers for any single purpose (Mian and Smith, 1990).

The literature on segment reporting also provides some evidence on this issue. Maines et al. (1997) show that, consistent with FASB's expectations when issuing SFAS 131, analysts view segment data as more reliable when externally reported segment definitions are congruent with internal segment definitions. The segment information produced using the FASB's management approach may be perceived as more reliable since it is used internally and not developed solely for external reporting. This approach suggests that segment information is more likely to be reliable in the sense that managers rely on it and it is not arbitrary as far as the enterprise is concerned (Maines et al., 1997). However, Nichols and Street (2007) show that the flexibility in segment determination persists when the management approach (IAS 14 revised) is used given that the new standard continues to allow managers to aggregate industry segments. They provide evidence that managers are less likely to disclose segments separately when the segmental profit performance (e.g. return on assets) exceeds the industry average. Therefore, other incentives could result in managers not reporting externally some information that is appropriate and used for internal purposes. In our research we also find that the method that we assume to be more appropriate for internal reporting is sometimes not used by managers for external reporting so as to avoid for example debt covenant costs or monitoring costs.

\section{Hypothesis for the Determinants of the Accounting Choice}

Figure 1 provides an overview of the theory developed in this section. Starting at the top of Figure 1, three forms of inter-organizational cooperation are identified, namely arm's length contracts, acquisitions and joint ventures.

Arm's-length contracts do not involve the contribution of assets and capital by participants, which is why they are the least complex form of inter-organizational cooperation. The purchaser has no control over the assets and liabilities used to provide the products or services described in the contract and, therefore, those assets and liabilities are not reported in the purchaser's Balance Sheet. However, when the market for those products or services fails, ${ }^{9}$ all other forms of inter-organizational cooperation are more efficient.

Acquisitions involve the parent's contribution of assets and capital and are therefore a more complex form of inter-organizational cooperation than a simple contract. Because only the parent maintains its autonomy, this form of cooperation is distinct from a joint venture. The purchaser (parent) has total control over the assets and liabilities used to provide the subsidiary's products or services and, therefore, those assets and liabilities are presented in the parent's Balance Sheet (Full consolidation). However, several studies based on the transaction costs theory show that when the acquisition costs or the post acquisition integration costs are significant, joint ventures could be a more 


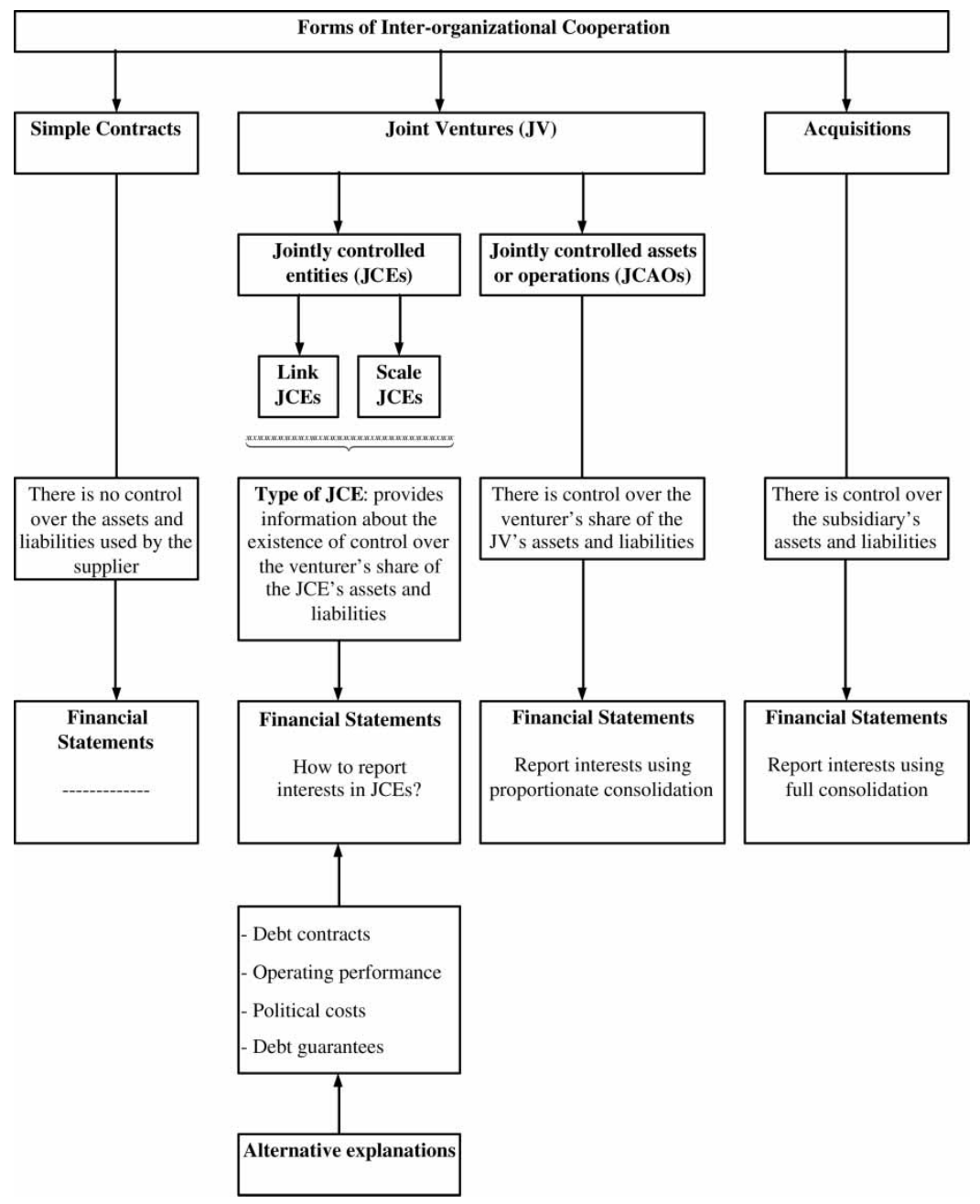

Figure 1. Overview of the theoretical framework for the accounting choice to report interests in JCE by the equity method or by proportionate consolidation.

efficient form of inter-organizational cooperation than acquisitions (e.g. Hennart, 1988, 1991; Balakrishnan and Koza, 1993; Hennart and Reddy, 1997; Chen and Hennart, 2004).

Joint ventures also involve the contribution of assets and capital by participants and are a more complex form of inter-organizational cooperation than simple arm's-length contracts. Because both venturers maintain their autonomy, this form of cooperation is distinct from acquisitions. Figure 1 identifies two kinds of joint venture: Jointly Controlled Assets or Operations (JCAOs) and Jointly Controlled Entities (JCEs). 
JCAOs involve the contribution of assets and capital by venturers in order to achieve their mutual task. Since no separate business entity is created, the mutual task is achieved inside the venturers' firms. The venturers have some control over their share of the jointly controlled assets and liabilities or operations and, thus, they report it in their financial statements (Proportionate consolidation).

Although JCEs also involve the contribution of assets and capital by venturers in order to achieve their mutual task, a separate business entity is created. However, there is no consensus about how an interest in a JCE should be reported in the venturers' financial statements. Proponents of the equity method argue that the venturer has no control over its share of the JCE's assets and liabilities but only has control over the financial interest in the JCE; hence, JCEs and JCAOs should be reported differently. Proponents of the proportionate consolidation argue that the venturer has some kind of control over its share of the JCE's assets and liabilities, similar to the control that a venturer has over its share of jointly controlled assets and operations; hence JCEs and JCAOs should be reported in the same way. In order to solve this problem, it is necessary to learn more about the nature of the JCEs. Hennart (1988) contrasts two types of JCEs: Scale and Link.

\section{Scale JCES}

According to Hennart (1988), Scale JCEs arise when venturers seek to internalize a failing market, but indivisibles due to scale or scope economies make full ownership of the relevant assets inefficient. This kind of JCE allows venturers to reconcile the need to bridge a failing market with the presence of large differences in the minimum efficient scale across successive stages.

This can be made clearer with an example. Consider the automobile industry. Automobile assemblers purchase standard components from large independent suppliers but face a problem when purchasing components specific to their models (e.g. engine). The market for these specific components tends to be thin, exposing parties to opportunistic behaviour i.e. it is a failing market due to high transaction costs. Therefore, automobile assemblers find it necessary to integrate backward into the production of those specific components. Whenever the minimum efficient scale is larger at the components production than at the assembly level, automobile assemblers join forces and produce components through a joint venture (Scale JCE). Were it not for high transaction costs in the market for those specific components, their production would be undertaken by some large independent suppliers, each of whom holds a widely diversified portfolio of potential automobile assemblers.

The venturers of a Scale JCE belong to the same industry (e.g. they are both automobile assemblers) and they enter a contiguous stage of production or distribution or a new market together (e.g. specific component production). They create the JCE instead of buying the components from an independent party 
only as a way of avoiding the failing market transaction costs. A Scale JCE is therefore a case of homogeneous cooperation.

\section{Link JCEs}

According to Hennart (1988), Link JCEs arise when there is simultaneous failing of the markets for the services of two or more assets whenever these assets are firm-specific public goods and the acquisition of the firm holding them would entail significant management costs. Assets are (i) firm-specific when they cannot be dissociated from the firm itself even though they often constitute a small part of the firm's assets, and are (ii) a public good when they can be shared at low marginal costs.

This can be made clearer with an example. Consider, on one hand, one of the world's leading manufacturer of milk products, which is entering a new country and suffers from a lack of country-specific distribution know-how and, on the other hand, a local distributor that is looking for leading trademarks to sell. The manufacturing of milk products should comply with specific patterns of quality. As this quality cannot be evaluated before its purchase, buyers will be willing to pay a premium for a trademarked milk product. However, the greater the trademark weight, the greater the possibility of opportunistic behaviour by the manufacturer. The market for the leading manufacturer's milk products is therefore a failing market. The distribution of milk products requires a high optimal level of dedicated investment in specialized facilities (e.g. refrigeration). Considering the possible opportunistic behaviour by the manufacturer, the distributor tries to reduce his loss by minimizing the investments supporting the sale of those products, which could debase their quality. Therefore, the distribution of trademarked milk products is also a failing market.

The two failing markets mentioned above are supported by two important assets: the manufacturer's trademark and technological know-how and the distributor's specific-country distribution know-how. These two different assets are firm-specific in the sense that they could not be sold independently from the firm itself; they are also a public good in the sense that someone could use it with zero or low marginal costs. The acquisition of the firms holding those assets is out of the question because it would entail significant management costs. Thus, both manufacturer and distributor find it necessary to join forces in order to produce and distribute those trademarked milk products through a joint venture (Link JCE).

The venturers of a Link JCE come from different industries (e.g. one is a manufacturer and the other is a distributor) entering a new business together (e.g. the distribution of the leading manufacturer's milk products in a specific country) and each contributes in a different way to the development of that new business. Each of the venturers creates the JCE instead of establishing a contractual relation with the other venturer; he thus avoids the transaction costs of the other venturer's failing market at the expense of losing the possibility of benefiting from the 
transaction costs of their own market (e.g. the manufacturer will avoid the distribution transaction costs at the expense of a loss in the capacity to account a gain through an opportunistic behaviour in their own market and vice versa). A Link JCE is therefore a case of heterogeneous cooperation.

\subsection{Type of JCE and the Accounting Choice}

The interest in a Scale JCE is a way of avoiding the transaction costs of a failing market (e.g. the possibility of opportunistic behaviour by engine producers). This interest should be seen as a kind of guarantee for the binomial quality/price of the supplies (e.g. engines). The venturer's relationship with a Scale JCE is similar to that with a third party with whom it has an arm's-length contract but where the venturer is protected by a guarantee (the common-control over that thirdparty). This kind of relationship is therefore closer to the relationship with an associate over whom the investor has significant influence. Accordingly, the equity method seems more appropriate for reporting interests in Scale JCEs.

The interest in a Link JCE is a way of avoiding the transaction costs of a failing market for the other venturer's firm-specific public asset (e.g. specific-country distribution know-how), but at the expense of sharing their own firm-specific public asset for which there is also a failing market (e.g. technological knowhow). Therefore, the venturer's relationship with a Link JCE is not like one with a third party. Each of the venturers contributes with different critical resources in order to achieve a mutual task through the Link JCE. Due to this significant wrapping up and reciprocity of the venturers, the relationship between a venturer and a Link JCE is closer to one with a JCAO. Hence, the proportionate consolidation seems to be a more appropriate method for reporting interests in Link JCEs.

Three UK venturers applying proportionate consolidation sent Comment Letters to the IASB Exposure Draft on Joint Ventures. They are all included in our sample and they are classified as Link. These venturers argue that proportionate consolidation is used both for internal and external purposes and two of them support their decision based on the type of relationship with the joint venturers. More specifically, The Serco Group argues that: 'Our joint ventures are arrangements where the venture parties offer differing skills and experiences, but the risks and rewards of the arrangements and control over the management of the businesses is shared [...] to treat joint ventures in the same way as associates would devalue our role in the joint ventures [...] we believe that proportionate consolidation is a more appropriate method for accounting for our joint ventures than equity method' (Comment Letter 101). The John Wood Group argues that 'In such joint ventures, although we operate in a regime of joint control over all material matters, we have a significant involvement in a day-to-day management of the business activities. We believe that the proportionate consolidation method is the most appropriate accounting treatment to reflect the substance of the arrangements' (Comment Letter 57). ${ }^{10}$ 
Previous research already provides some empirical evidence on this issue. For example, Mian and Smith (1990) found that prior to the Financial Accounting Standards Board Statement 94 in the United States the greater the operating and informational interdependencies between parent and financial subsidiary the more US parents were likely to report operations of a financial subsidiary on a consolidated basis. We extend this to the case of joint ventures.

Finally, given that managers sometimes exercise their discretion to choose the accounting method based on their insights into the underlying economics of their firms (e.g. Mian and Smith, 1990; Whittred and Zimmer, 1994; Wyatt, 2005), we hypothesize that the type of JCE (Scale or Link) will map into the accounting choice through its influence on management beliefs about the degree of control over the venturer's share of the JCE's assets and liabilities. In addition, bearing in mind that venturers have to choose a reporting method for all the interests in JCEs and not for each of them individually, the following relationship is expected between the type of JCE and the accounting choice for reporting interests in JCEs: as the majority of a venturer's JCEs is Link, the venturer is more likely to report interests in JCEs by proportionate consolidation than by the equity method.

\subsection{Alternative Explanations of the Accounting Choice}

This section discusses alternative explanations for the management choice between reporting interests in JCEs using the equity method or proportionate consolidation based on prior literature on accounting choice.

\section{Debt contracts}

Assuming that a venturer's proximity to covenant limits and the cost of violating those covenants are both positively related to its leverage (Duke and Hunt, 1990; Press and Weintrop, 1990), and bearing in mind that the change to proportionate consolidation carries an increase in leverage, a negative relationship between leverage and the choice of proportionate consolidation is predicted. Some studies measure the proximity to covenant limits based on leverage in relative rather than absolute terms (e.g. Georgiou, 2005). Thus, a negative relationship could be expected between a venturer with a leverage ratio above the industry median and the choice of proportionate consolidation. Otherwise, as venturers with leverage above the industry median have no incentives to change to proportionate consolidation, a negative relation could be expected between leverage and the change to proportionate consolidation only for those venturers whose leverage is below the industry median.

However, there has been considerable debate in the accounting literature as to how well high leverage proxies for the proximity of covenant limits and for debt covenant costs (Fields et al., 2001). Furthermore, much of the research that uses leverage as a proxy for the proximity of covenant limits has been based on US 
data and on public debt. As both the type of debt and the factors driving the incidence of accounting-based covenants in public debt agreements are different in the UK from those in the US, this subject requires further analysis. Citron (1995) identifies some important institutional differences between public debt in the UK and the US. The UK public market is relatively small in comparison with that of the US and it is generally only high quality firms that obtain access to this market. The UK insolvency procedures afford unambiguous protection to secured creditors. Accounting-based covenants are thus used in only a small number of public debt contracts and they are associated with long-term unsecured debt. ${ }^{11}$ As a result, attention should be directed to private debt.

Accounting-based covenants are widely used in UK private debt. In contrast with public debt, there is a greater diversification of covenants because the range and type of covenants are negotiated directly between the lender and the borrower, and renegotiations are a usual procedure. However, most covenants in UK private debt contracts relate to leverage and interest cover (Moir and Sudarsanam, 2007). ${ }^{12}$

Dichev and Skinner (2002) provide a discussion of the economics of private corporate lending. They point out that private lenders use debt covenants as an early warning signal to maintain close scrutiny over the performance of the borrower, implying that the information content and consequences of debt covenant violations are likely to vary depending on the borrower's economic circumstances. It is therefore unlikely that covenant violations are always, or even often, associated with financial distress and serious consequences for the borrower. Empirical evidence provided by Dichev and Skinner (2002) shows that the extensively-used leverage variable is a relatively poor proxy for the proximity to covenant limits enclosed in private debt agreements.

Smith (1993) argues that one stylized strategy that private lenders can follow is to set debt constraints just below the actual current value. If the firm's operating performance is in line with or better than normal business, covenants are not violated and the debt is serviced as normal. If, on the other hand, the firm's operating performance deteriorates, covenants are quickly violated, giving the lenders the ability to reassess the loan. If the deterioration continues, the lender renegotiates again and may eventually get to the point where more drastic alternatives are necessary.

This lending strategy produces a dynamic interaction between borrower and lender that provides ongoing flexible monitoring of the borrower and potential interest rate adjustments. Significant operating performance deterioration could make a favourable leverage become unfavourable to the firm. Whenever this is the case, the firm's return on assets becomes lower than the cost required to pay for the use of the borrowed funds. Thus, borrowing is now not justified and most common covenants in private debt (leverage and interest cover) are probably violated $^{13}$ and renegotiation with lenders is required.

As the benefits of avoiding covenant violation increase when leverage becomes unfavourable, managers of venturers whose return on assets is lower than the 
cost of debt attempt to maintain the equity method in order to avoid such violations. A negative relation is therefore expected between a venturer to have a return on assets lower than the cost of debt and the change to proportionate consolidation.

\section{Operating performance}

The change to proportionate consolidation usually carries a decrease in the Return on Assets (ROA). Thus, a positive relation is predicted between ROA and this change. A positive relation could also be expected between a venturer to have a ROA above the industry median and the change to proportionate consolidation.

\section{Significance of change}

The change to proportionate consolidation by UK firms means a change in the status quo, which could bring additional costs to the firms, mainly to those applying the equity method for internal purposes. Assuming the change does not result in benefits, the UK listed firms would expect each other not to apply proportionate consolidation in the transition to IFRS. Considering that in order to reduce shareholders' monitoring costs, a firm adopt those accounting methods employed by other firms facing a similar economic environment (Knoeber and McKee, 1991), we would expect an alignment of the UK firms focusing on the equity method. Assuming that shareholders estimate managers' performance based on accounting information and that they construct a relative accounting performance measure (e.g. the return on assets) using only the performance of those other firms applying the same accounting method, the firm's accounting choice determines which other firms can be used as benchmarks to evaluate its manager and thus affect monitoring costs (Knoeber and McKee, 1991). ${ }^{14}$ Therefore, a venturer can be expected to choose the most widely used method, i.e. the equity method to minimize monitoring costs,.

However, we also predict that venturers may have incentives to change their reporting method of interests in JCE to proportionate consolidation, namely when the majority of their JCEs are Link. Such firms will change the accounting method when the benefits of this change outweigh its costs. We assume that monitoring costs would be an influential variable only when the change to proportionate consolidation, as opposed to the equity method has a significant impact on the main balance sheet measures (total assets and total liabilities). Otherwise, shareholders could compare the performance measures of firms using proportionate consolidation with those using the equity method without risk of compromising their decisions. Therefore, a negative relation is predicted between a significant impact of the change to proportionate consolidation in the venturer's total assets and total liabilities and the choice of proportionate consolidation. 


\section{Political costs}

Managers sometimes make an accounting choice so as to minimize firm's political costs. Assuming that larger firms are more likely to face political exposure penalties than smaller firms, managers of larger venturers may have incentives to report interests in JCEs by the equity method in order to avoid a significant change in the status quo. Thus, a negative relationship is predicted between the venturer's size and the choice of proportionate consolidation.

\section{Debt guarantees}

Previous studies on accounting choice document a positive relationship between the adoption of consolidated reporting and the presence of inter-company guarantees (e.g. Whittred, 1987; Mian and Smith, 1990; Whittred and Zimmer, 1994). Some argue that cross-guarantees among related companies avoid the costs of prohibiting asset transfers within the group while controlling incentives to use such transactions to transfer wealth from borrowing company creditors. Thus, consolidation facilitates monitoring compliance with contracts where guarantees are offered. Studies on the value-relevance of proportionate consolidation figures or on the value relevance of disclosures of the venturer's share of JCE's liabilities provide additional evidence on this issue (e.g. Bauman, 2003; Stolzfus and Epps, 2005; O'Hanlon and Taylor, 2007). They document that a change to proportionate consolidation or the disclosure of JCE's liabilities would provide more value-relevant information, especially when the venturer guarantees the debt of the joint ventures. Unlike the former studies, in which the results are based on samples and time periods that vary greatly from those used in our research, the latter studies are based on a large sample of US and UK firms. However, the results seem to highlight the importance of guarantees both for preparers and users of financial statements. Hence, a positive relationship is predicted between the venturers providing financial guarantees to JCEs and the choice of proportionate consolidation.

\section{Research Design}

\subsection{Data Collection and Analysis}

Our analysis relies on firms listed in the London Stock Exchange belonging to the FTSE All Shares and that changed their accounting standards to IFRS compulsory by the financial year beginning on or after 1 January $2005 .{ }^{15}$ The name and the website of each of these firms are drawn from the Thomson Worldscope Database. We started by collecting the first annual consolidated financial statements presented according to IFRS from the firms' website. We then selected only those firms that report interests in JCEs. Thus, our sample consists of 159 firms (venturers).

The dependent variable is the reporting method used by venturers to report interests in JCEs following the adoption of IFRS, which is identified in the 
above-mentioned consolidated financial statements. The sample includes both venturers that report interests in JCEs by the equity method $(125 / 159)$ and by proportionate consolidation (34/159). The most important independent variable is the type of venturer, considering whether the majority of its JCEs are Scale or Link. It is impossible to use the type of JCE as independent variable because the venturers have to choose the accounting method for reporting all of their interests in JCEs, as opposed to the reporting method for each one of them. However, we can expect the venturers' choice of reporting method to be based on the type of the majority of their JCEs. Thus, two types of venturers are identified: the venturers where the majority of JCEs are Scale (Scale Venturers) and the venturers where the majority of JCEs are Link (Link Venturers).

Prior to classifying each venturer as Scale or Link, their JCEs must be classified and this was done using the following procedure. First, we identified the names of the JCEs for each venturer from the Notes included in the first consolidated financial statements prepared according to IFRS. We then looked for information about each JCE's business as well as the venturers' business in order to analyze and draw conclusions about the role of each venturer in the JCE. When the business of the venturer under consideration is complementary to that of some other venturers, the JCE is a case of heterogeneous cooperation and is therefore classified as a Link JCE. When all the venturers undertake a similar business, the JCE is a case of homogeneous cooperation and is classified as a Scale JCE.

Our primary source of information is the JCE website, where we looked for information about the JCE's business and venturers. Second, we searched for information about the venturers' business in the JCE website or, alternatively, in each venturer's websites. Finally, and based on the business descriptions, we classified the JCEs into Scale or Link. For example, the South East Australia (SEA Gas) is one of the JCEs identified in the Notes of the International Power Group. As a first step, we searched for the website of this JCE (www.seagas.com. $\mathrm{au}$, from which we collected information about this JCE's business and venturers. The SEA Gas is identified as a partnership that was established to develop, own and operate the underground pipeline system transporting natural gas from the Otway and Bass Basins to South Australia and Victoria. The SEA Gas is neither a retailer nor producer of natural gas but can be considered a road train carrying large volumes of its customers' goods (in this case, natural gas) to major depots (delivery points). The SEA Gas's venturers are International Power and APA Group. The second step was to search for the website of these two venturers in order to find information about their businesses. The International Power is a growing, independent power generation company with interests in over 45 power stations and some closely linked business around the world (www.ipplc.com). The APA Group is a leader in energy transport in Australia with interests in well over $10,000 \mathrm{~km}$ of gas transmission pipelines serving all mainland states (www.apa.com.au). These two venturers come from different industries (power generation and energy transportation) and they have entered 
a new business together (operating a specific underground pipeline). This JCE is a case of heterogeneous cooperation and is therefore classified as Link.

In cases where the JCE website was not available, we looked for alternative sources of information about the JCE's business and venturers. This was usually found in the venturer's annual report or website. For example, the Lakeside Energy from Waste is one of the JCEs identified in the Notes of the Pennon Group. As the website of this firm is not available, we started by looking in the Pennon Group Financial Report. We found information in the Chairman's Statement about the JCE's business and venturers, namely that Viridor waste (one of the Pennon Group's main subsidiaries) established a 50:50 joint venture company with Grundon Waste Management and the new business - Lakeside Energy from Waste - will build and operate an energy-from-waste plant in Colnbrook, near Heathrow. The plant will have a capacity of 200,000 tonnes of waste per annum and will provide a power generation capacity of 32 megawatts of electricity. The second step was to search for the website of the two venturers to find information about their businesses. The Viridor Waste is one of the UK's leading waste management companies (www.pennon-group.co.uk). The Grundon Waste Management is the largest privately owned waste management group in the UK (www.grundon.com). These two venturers belong to the same industry (waste management) and they have entered a contiguous stage of production together (energy from waste). The Lakeside Energy from Waste is a case of homogeneous cooperation and is therefore classified as Scale.

Another example is the Salvesen Logistica, a JCE identified in the Notes of Christian Salvesen. As the website of this firm is not available, we started by looking for information in the Christian Salvesen financial report and we identify the Danone Group as the other Salvesen Logistica's venturer in the Note on Investments in Associates and Joint Ventures. In the Operation Review section we found information about the JCE's business. The Salvesen Logistica is incorporated in Spain and operates a shared-user, chilled food distribution network throughout Portugal and Spain. Danone products are the main activity of this JCE. As a second step, we search for the website of the two venturers in order to find information about its business The Salvesen Logistica is a logistics group operating in some European countries. Its industry specializations are food, consumer goods and consumer manufacturing for a wide portfolio of household names (www.salvesen.com). Danone is an international leader in fresh dairy products (www.danone.com). These two venturers come from different industries (logistic and dairy products manufacturing) and they have entered to a new business together (the distribution of chilled food in Portugal and Spain). This JCE is a case of heterogeneous cooperation and is therefore classified as Link.

In the exceptional cases where we could not find the information in either the venturer's annual report or website, we did an internet search with the JCE's names for anything that could help us to glean information about the JCEs business and other venturers. This includes, for example, news about acquisitions and disposals of joint venturers. In the few situations where no information was available, 
we could not classify the JCE. However, the lack of classification of that JCE would not affect the final classification of the Venturer in any of these cases.

There are some venturers where the number of Link JCEs is much the same as the number of Scale JCEs. These venturers apply the equity method and were classified as Scale but the final results would remain unchanged if they had been classified as Link. The return on assets of all these venturers is lower than the cost of debt; this is one of the determinants that we found for Link ventures to report interests in JCEs by the equity method.

Finally, other independent variables are used in order to control for alternative explanations of the accounting choice. Data used to compute these variables are collected from the Thomson Worldscope Database ${ }^{16}$ and from the last annual consolidated financial statements prepared according to UK GAAP.

\subsection{Measurement of Variables}

In order to test the hypothesis described in Section 3, some variables are identified and computed. Table 1 provides details of those variables. The dependent variable is the Reporting Method for interests in JCEs used by venturers in their first annual consolidated financial statement presented according to IFRS (REPORTING METHOD). This variable assumes just two values: 0 if the venturer chose to report interests in JCEs by the equity method and 1 if the venturer chose to report interests in JCEs by proportionate consolidation. The most important independent variable is the Type of Venture (TYPE) which assumes the value 0 for the Scale Venturers and assumes 1 for the Link Venturers. ${ }^{17}$

The other independent variables are: the venturer's leverage (LEV), the position of the venturer's leverage in relation to the industry median (LEV_Position), the venturer's return on assets (ROA), the position of the venturer's return on assets in relation to the industry median (ROA_Position), the venturer's assets (Assets), the position of the venturer's assets in relation to the industry median (Assets_Position), the relation between the venturer's return on assets and cost of debt (ROAversusCD), the impact that the adoption of proportionate consolidation instead of the equity method has (or would have for venturers not switching to proportionate consolidation) on the venturer's assets and liabilities (ImpChange) and whether the venturer provides financial guarantees to JCEs' debt (Guarantees).

The LEV_Position, the ROA_Position, the Assets_Position, the ROAversusCD, the ImpChange and the Guarantees are all binary variables. The LEV Position assumes the values 0 and 1 when the venturer's leverage is above or below the industry leverage median, respectively. The ROA_Position assumes the values 0 and 1 when the venturer's return on assets is below or above the industry return on assets median, respectively. The Assets_Position assumes the values 0 and 1 when the venturer's ROA is above or below the industry assets median, respectively. The ROAversus CD assumes the value 0 when the venturer's return on assets is lower than the venturer's cost of debt and assumes the value 1 otherwise. The ImpChange assumes the value 0 when the 
Table 1. Independent variables definition and measurement

\begin{tabular}{|c|c|c|}
\hline Variable name & Variable label & Variable measurement \\
\hline \multicolumn{3}{|c|}{ Panel A: Binary variables } \\
\hline TYPE & Type of venturer & $\begin{array}{l}0 \text { if the majority of the venturer's JCEs } \\
\text { are Scale } \\
1 \text { if the majority of the venturer's JCEs } \\
\text { are Link }\end{array}$ \\
\hline LEV_Position & $\begin{array}{l}\text { Position of the venturer's } \\
\text { leverage in relation to } \\
\text { industry median }\end{array}$ & $\begin{array}{l}0 \text { if the venturer's leverage is above } \\
\text { industry median } \\
1 \text { if the venturer's leverage is below } \\
\text { industry median }\end{array}$ \\
\hline ROA_Position & $\begin{array}{l}\text { Position of the venturer's } \\
\text { return on assets in relation } \\
\text { to industry median }\end{array}$ & $\begin{array}{l}0 \text { if the venturer's ROA is below } \\
\text { industry median } \\
1 \text { if the venturer's ROA is above } \\
\text { industry median }\end{array}$ \\
\hline Assets_Position & $\begin{array}{l}\text { Position of the venturer's } \\
\text { total assets in relation to } \\
\text { industry median }\end{array}$ & $\begin{array}{l}0 \text { if the ventureŕs assets is above } \\
\text { industry median } \\
1 \text { if the ventureŕs assets is below } \\
\text { industry median }\end{array}$ \\
\hline ROAversusCD & $\begin{array}{l}\text { Relation between the } \\
\text { venturer's return on assets } \\
\text { and cost of debt }\end{array}$ & $\begin{array}{l}0 \text { if the venturer's ROA is lower than its } \\
\mathrm{CD} \\
1 \text { if the venturer's ROA is higher than } \\
\text { its } \mathrm{CD}\end{array}$ \\
\hline ImpChange & $\begin{array}{l}\text { Impact that the adoption of } \\
\text { proportionate } \\
\text { consolidation instead of } \\
\text { the equity method has or } \\
\text { would have on the } \\
\text { venturer's assets and } \\
\text { liabilities }\end{array}$ & $\begin{array}{l}0 \text { if the impact on the venturer's assets } \\
\text { and liabilities is or would be lower } \\
\text { than } 20 \% \\
1 \text { if the impact on the venturers assets or } \\
\text { liabilities is or would be higher than } \\
20 \%\end{array}$ \\
\hline Guarantees & $\begin{array}{l}\text { Venturer's financial } \\
\text { guarantees to JCEs debt }\end{array}$ & $\begin{array}{l}0 \text { if the venturer does not provide } \\
\text { guarantees } \\
1 \text { if the venturer provides guarantees }\end{array}$ \\
\hline Variable name & Variable label & Variable measurement \\
\hline \multicolumn{3}{|c|}{ Panel B: Continuous variables } \\
\hline LE & s leverage & $\begin{array}{l}\text { Venturer's debt divided by market } \\
\text { capitalization }\end{array}$ \\
\hline ROA & Venturer's return on assets & $\begin{array}{l}\text { Venturer's earnings before interests } \\
\text { expense on debt divided by the } \\
\text { previous year's total assets }\end{array}$ \\
\hline Assets & Venturer's assets & Venturer's total assets (logarithm) \\
\hline
\end{tabular}

adoption of proportionate consolidation instead of the equity method has a less than $20 \%$ impact on the venturer's assets and liabilities, considering either those venturers switching to proportionate consolidation or those applying the equity method, and assumes the value 1 otherwise. Finally, Guarantees assumes the value 0 when the venturer did not provide any financial guarantee 
to JCEs' Debt and assumes 1 otherwise. LEV, ROA and Assets are all continuous variables. LEV is the venturer's debt divided by its market capitalization, ROA is the venturer's earnings before interest expenses on debt divided by the last year's total assets and Assets is the venturer's total assets (we use the logarithm of assets in order to reduce the original scale).

All of these variables are computed immediately before the change from UK GAAP to IFRS and considering interests in JCEs reported by the equity method. Data used to compute some of these variables are collected from the last annual consolidated financial statements prepared according to UK GAAP. In the particular case of the variable ImpChange, total assets and total liabilities needs to be computed based on either the equity method or proportionate consolidation. The information provided by venturers in their consolidated financial statements is used as equity method financial amounts. Pro forma proportionate consolidation amounts are computed based on the additional information on the venturer's share of JCEs' assets and liabilities provided by the venturers in the face of their balance sheet. ${ }^{18}$ According to IFRS, venturers also have to provide appropriate disclosures in the Notes on the aggregate amount of current asset, long-term assets, current liabilities and long-term liabilities related to the venturer's share of JCEs. This information is very important in order to improve the comparability of the venturers' financial statements. Almost all the firms analysed in this study comply with this requirement in their first consolidated financial statements prepared according to IFRS. Therefore, a possible trend of non compliance by those firms that switch to proportionate consolidation is not an issue that could affect our results.

Finally, we also considered independent dummy variables for each of the one-digit SIC code industries in order to control for the effect of the firm's industry.

\subsection{Research method}

To test the hypothesis formulated in Section 3, first we performed univariate comparisons based on descriptive statistics and tests of equality for the central tendency measures in the case of continuous variables, and tests of equality of proportions in case of binary variables. Secondly, we estimated several logistic regression models.

\section{Univariate comparisons}

As firms are divided into two groups according to the method chosen to report interests in JCEs - the equity method and proportionate consolidation - we first computed for each of these two groups the mean and median of the continuous variables and the frequencies for each binary variable that represent the most relevant subjects in our empirical analysis. Secondly, we applied the equality of means parametric t-test, and the non-parametric Mann-Whitney test when the 
normality or the variance equality assumptions underlying the t-test are not met, to compare the resulting groups in terms of the continuous variables of our study. For the binary variables, the test for the difference of proportions is computed.

Furthermore, as the impact of some variables on the decision to report JCE interests using either the equity method or proportionate consolidation can be different for the Link Venturers, when compared to the Scale Venturers, we also performed univariate analyses for each one of these resulting groups. Thus, in Tables 2 and 3 statistical results refer to all firms (All venturers) and to each of these two particular sets: Scale Venturers (TYPE $=0$ ) and Link Venturers (TYPE $=1)$.

\section{Logistic regressions}

The univariate comparisons are complemented by the estimation of several logistic regressions. With this econometric model, conclusions can be drawn about the interrelations between the independent variables and their impact on the probability of reporting interests in JCEs by proportionate consolidation instead of the equity method. The equation of the main logistic regression is:

$$
\left(Y_{i}=1\right)=E\left(Y_{i}=1 \mid X_{1 i}, X_{2 i}, \ldots, X_{11 i}\right)=\frac{1}{1+e^{-\left(\alpha+\beta_{1} X_{1 i}+\ldots+\beta_{11} X_{11}\right)}}
$$

where $e$ represents the exponential and

$$
\begin{aligned}
& \left.\begin{array}{l}
Y=\text { REPORTING METHOD; } \\
X_{1}=\text { TYPE; } \\
X_{2}=\text { LEV; } \\
X_{3}=\text { LEV_Position; }
\end{array}\right\} \text { or } X_{23}=\text { LEV } \times \text { LEV_Position } \\
& X_{4}=\text { Assets; } \\
& X_{5}=\text { Assets_Position; } \\
& X_{6}=\text { ROA; } \\
& X_{7}=\text { ROA_Position; } \\
& X_{8}=\text { ROAversusCD; } \\
& X_{9}=\text { ImpChange; } \\
& X_{10}=\text { Guarantees; } \\
& X_{11}=\text { Industry dummy variables, with } j=1,2, \ldots, 7 .
\end{aligned}
$$

For the reasons mentioned above, we also estimated the logistic regression for each of the groups of venturers identified based on the type of JCEs: Scale Venturers $($ TYPE $=0)$ and Link Venturers $($ TYPE $=1)$. In these two additional 
regressions, variable $X_{1}$ was excluded from the model. The objective of this analysis is to identify the variables that have a significant impact on the probability of reporting interests in JCEs by proportionate consolidation instead of the equity method in just one of these two sets of venturers.

\section{Results}

Tables 2 to 6 report the statistical results. Tables 2 and 3 summarize the empirical results from the univariate comparisons, while Tables 4, 5 and 6 report findings from binary logistic regressions.

\subsection{Univariate Comparisons}

Tables 2 and 3 provide the mean and the median as well as the central tendency equality tests results for each of the continuous variables; they also provide the frequencies as well as the results of the tests for the difference of proportions for each of the binary variables.

\section{Type of JCEs hypothesis}

Table 2 (Panel A) presents the number of Scale Venturers $($ TYPE $=0$ ) and the number of Link Venturers (TYPE $=1$ ) that adopt each of the reporting methods for interests in JCEs, as well as the results of the test for the difference in proportions. As expected, $46 \%$ of the Link Venturers have changed their reporting method for interests in JCEs to proportionate consolidation while just $7 \%$ of the Scale Venturers made that change. According to the result of the test for the difference of proportions $(-6.43)$ and its associated significance $(p$-value $=0.000)$ the percentage of change to proportionate consolidation in the Link Venturers is statistically higher than the percentage of change in the Scale Venturers. Based on this, we can conclude that data supports our hypothesis: as the majority of a venturer's JCEs are Link, the venturer is more likely to report interests in JCEs by proportionate consolidation than by the equity method.

However, the percentage of Link Venturers that chose to apply the equity method $(54 \%)$ is still considerable. This highlights that other variables could support the decision made by this type of Venturer to report interests in JCEs using either the equity method or proportionate consolidation. The empirical analysis of the alternative explanations for the accounting choice provides evidence on this prediction.

\section{Alternative explanations of the accounting choice}

Table 2 (Panel A) presents the empirical results for the binary variables. The percentage of venturers reporting interests in JCEs by proportionate consolidation is around $20 \%$ in the case of venturers whose return on assets is either above or 
Table 2. Univariate comparisons - excluding industry dummies

\begin{tabular}{|c|c|c|c|c|c|c|c|c|c|c|c|c|c|c|c|}
\hline & \multicolumn{5}{|c|}{ All Venturers } & \multicolumn{5}{|c|}{$\mathrm{TYPE}=0$} & \multicolumn{5}{|c|}{$\mathrm{TYPE}=1$} \\
\hline & \multicolumn{2}{|c|}{ EM } & \multicolumn{2}{|c|}{$\mathrm{PC}$} & \multirow[t]{2}{*}{ Total } & \multicolumn{2}{|c|}{ EM } & \multicolumn{2}{|c|}{$\mathrm{PC}$} & \multirow[t]{2}{*}{ Total } & \multicolumn{2}{|c|}{ EM } & \multicolumn{2}{|c|}{$\mathrm{PC}$} & \multirow[t]{2}{*}{ Total } \\
\hline & $\mathrm{n}$ & $\%$ & $\mathrm{n}$ & $\%$ & & $\mathrm{n}$ & $\%$ & $\mathrm{n}$ & $\%$ & & $\mathrm{n}$ & $\%$ & $\mathrm{n}$ & $\%$ & \\
\hline \multicolumn{16}{|c|}{ Panel A: Binary variables } \\
\hline \multicolumn{16}{|c|}{ TYPE } \\
\hline $\mathrm{TYPE}=0$ & 93 & $93 \%$ & 7 & $7 \%$ & 100 & - & - & - & - & - & - & - & - & - & - \\
\hline TYPE $=1$ & 32 & $54 \%$ & 27 & $46 \%$ & 59 & - & - & - & - & - & - & - & - & - & - \\
\hline Comparison test $^{1}$ & & & & & $-6.43^{* * *}$ & & & & & & & & & & \\
\hline \multicolumn{16}{|l|}{ LEV_Position } \\
\hline LevPosition $=0$ & 58 & $73 \%$ & 21 & $27 \%$ & 79 & 46 & $94 \%$ & 3 & $6 \%$ & 49 & 12 & $40 \%$ & 18 & $60 \%$ & 30 \\
\hline LevPosition $=1$ & 67 & $84 \%$ & 13 & $16 \%$ & 80 & 47 & $92 \%$ & 4 & $8 \%$ & 51 & 20 & $69 \%$ & 9 & $31 \%$ & 29 \\
\hline Comparison test $^{1}$ & & & & & 1.59 & & & & & -0.33 & & & & & $2.29^{* *}$ \\
\hline \multicolumn{16}{|l|}{ ROA_Position } \\
\hline RoaPosition $=0$ & 61 & $77 \%$ & 18 & $23 \%$ & 79 & 43 & $91 \%$ & 4 & $9 \%$ & 47 & 18 & $56 \%$ & 14 & $44 \%$ & 32 \\
\hline RoaPosition = 1 & 64 & $80 \%$ & 16 & $20 \%$ & 80 & 50 & $94 \%$ & 3 & $6 \%$ & 53 & 14 & $52 \%$ & 13 & $48 \%$ & 27 \\
\hline Comparison test $^{1}$ & & & & & 0.43 & & & & & 0.55 & & & & & -0.33 \\
\hline \multicolumn{16}{|l|}{ Assets_Position } \\
\hline AsPosition $=0$ & 63 & $80 \%$ & 16 & $20 \%$ & 79 & 44 & $95 \%$ & 3 & $5 \%$ & 47 & 19 & $59 \%$ & 13 & $41 \%$ & 32 \\
\hline AsPosition $=1$ & 72 & $90 \%$ & 18 & $10 \%$ & 80 & 49 & $89 \%$ & 4 & $11 \%$ & 53 & 13 & $48 \%$ & 14 & $52 \%$ & 27 \\
\hline Comparison test ${ }^{1}$ & & & & & -0.34 & & & & & -0.23 & & & & & -0.85 \\
\hline \multicolumn{16}{|l|}{ RoaversusCD } \\
\hline $\mathrm{ROAversus} \mathrm{CD}=0$ & 73 & $80 \%$ & 18 & $20 \%$ & 91 & 45 & $94 \%$ & 3 & $6 \%$ & 48 & 28 & $65 \%$ & 15 & $35 \%$ & 43 \\
\hline ROAversus $\mathrm{CD}=1$ & 52 & $76 \%$ & 16 & $24 \%$ & 68 & 48 & $92 \%$ & 4 & $8 \%$ & 52 & 4 & $25 \%$ & 12 & $75 \%$ & 16 \\
\hline Comparison test $^{1}$ & & & & & -0.57 & & & & & -0.28 & & & & & $-2.90^{* * *}$ \\
\hline \multicolumn{16}{|l|}{ ImpChange } \\
\hline SigChange $=0$ & 105 & $77 \%$ & 32 & $23 \%$ & 137 & 85 & $92 \%$ & 7 & $8 \%$ & 92 & 20 & $44 \%$ & 25 & $56 \%$ & 45 \\
\hline SigChange $=1$ & 20 & $91 \%$ & 2 & $9 \%$ & 22 & 8 & $100 \%$ & 0 & $0 \%$ & 8 & 12 & $86 \%$ & 2 & $14 \%$ & 14 \\
\hline Comparison test ${ }^{1}$ & & & & & 1.52 & & & & & 0.80 & & & & & $2.84^{* * *}$ \\
\hline \multicolumn{16}{|l|}{ Guarantees } \\
\hline Guarantees $=0$ & 98 & $78 \%$ & 27 & $22 \%$ & 125 & 73 & $94 \%$ & 5 & $6 \%$ & 78 & 25 & $53 \%$ & 22 & $47 \%$ & 47 \\
\hline Guarantees $=1$ & 27 & $79 \%$ & 7 & $21 \%$ & 34 & 20 & $91 \%$ & 2 & $9 \%$ & 22 & 7 & $58 \%$ & 5 & $42 \%$ & 12 \\
\hline Comparison test $^{1}$ & & & & & 0.13 & & & & & -0.43 & & & & & 0.31 \\
\hline
\end{tabular}

TYPE $=0$ if the majority of the venturer's JCE are Scale and TYPE $=1$ otherwise; LEV_Position $=0$ if the venturer's leverage is above industry median and LEV_Position $=1$ otherwise; ROA_Position $=0$ if the venturer's return on assets is below industry median and ROA_Position $=1$ otherwise; Assets_Position $=0$ if the venturer's total assets is above industry median and Assets_Position $=1$ otherwise; ROAversusCD $=0$ if the venturer's return on assets is lower than cost of debt and ROAversusCD $=1$ otherwise; ImpChange $=0$ if the adoption of proportionate consolidation instead of the equity method has or would have less than $20 \%$ impact on the venturer's assets and liabilities and ImpChange $=1$ otherwise; Guarantees $=0$ if the venturer does not provide guarantees to JCES' debt and Guarantees $=1$ otherwise.

${ }^{1}$ Test of difference between proportions. ${ }^{* * *},{ }^{* *}$ and ${ }^{*}$ indicate significance at the $0.01,0.05$ and 0.10 levels respectively. 


\begin{tabular}{|c|c|c|c|c|c|c|c|c|c|}
\hline & \multicolumn{2}{|c|}{ All Ventures } & \multirow[b]{2}{*}{ Total } & \multicolumn{2}{|c|}{ TYPE $=0$} & \multirow[b]{2}{*}{ Total } & \multicolumn{2}{|c|}{$\mathrm{TYPE}=1$} & \multirow[b]{2}{*}{ Total } \\
\hline & EM & $\mathrm{PC}$ & & EM & PC & & EM & $\mathrm{PC}$ & \\
\hline \multirow{2}{*}{\multicolumn{10}{|c|}{$\begin{array}{l}\text { Panel B: Continuous variables } \\
\text { LEV }\end{array}$}} \\
\hline & & & & & & & & & \\
\hline Mean & 0.246 & 0.247 & 0.246 & 0.247 & $\begin{array}{l}0.199 \\
0157\end{array}$ & 0.243 & 0.245 & 0.260 & $\begin{array}{l}0.251 \\
0.222\end{array}$ \\
\hline Comparison test ${ }^{1}$ & 0.213 & 0.252 & $\begin{array}{l}0.222 \\
-0.03\end{array}$ & 0.225 & 0.157 & $\begin{array}{l}0.222 \\
0.69\end{array}$ & 0.177 & 0.261 & $\begin{array}{l}0.222 \\
-0.29\end{array}$ \\
\hline \multicolumn{10}{|l|}{ ROA } \\
\hline Mean & $6.3 \%$ & $6.3 \%$ & $6.3 \%$ & $6.9 \%$ & $7.5 \%$ & $6.9 \%$ & $4.6 \%$ & $6.0 \%$ & $5.3 \%$ \\
\hline Median & $6.4 \%$ & $6.2 \%$ & $6.3 \%$ & $6.5 \%$ & $6.3 \%$ & $6.5 \%$ & $5.5 \%$ & $4.9 \%$ & $5.3 \%$ \\
\hline Comparison test ${ }^{1}$ & & & 0.53 & & & -0.35 & & & -0.17 \\
\hline \multicolumn{10}{|l|}{ Assets } \\
\hline Mean & 3.142 & 3.078 & 3.128 & 3.146 & 3.384 & 3.162 & 3.131 & 2.999 & 3.070 \\
\hline Median & 3.110 & 3.067 & 3.098 & 3.110 & 3.189 & 3.141 & 3.106 & 3.043 & 3.052 \\
\hline Comparison test ${ }^{1}$ & & & 0.43 & & & -0.76 & & & 0.73 \\
\hline
\end{tabular}

TYPE $=0$ if the majority of the venturer's JCE are Scale and TYPE $=1$ otherwise; LEV $=$ debt divided by market capitalization; ROA $=$ earnings before interests on debt divided by the previous year's total assets; Assets $=$ total assets.

${ }^{1}$ Mann-Whitney test in the case of ROA, once normality assumption is rejected; t-test in the cases of LEV and Assets. ${ }^{* * *},{ }^{* *}$ and ${ }^{*}$ indicate significant at the 0.01 , 0.05 and 0.10 levels respectively. 
below the industry median, venturers whose return on assets is either higher or lower than the cost of debt and also venturers that provide or not financial guarantees on JCEs' debt. For the other three variables there is a difference between the two groups identified. The percentage of venturers reporting interests in JCEs by proportionate consolidation is higher in the case of venturers whose leverage is above the industry median, in the case of venturers whose assets are above the industry median and for the venturers where the impact of the adoption of proportionate consolidation instead of the equity method is lower than $20 \%$ of total assets and liabilities. However, the results of the test for the difference of proportions show that these differences are not statistically significant.

A separate analysis of Scale Venturers and Link Venturers reveals different findings. For the group of Scale Venturers, the results are similar to those of All Venturers. However, the results of the test for the difference of proportions for the group of Link Venturers are statistically significant for three variables: LEV_Position, ROAversusCD and ImpChange, but only two meet expectations. As predicted, the percentage of venturers reporting interests in JCEs by proportionate consolidation is statistically higher in the case of venturers whose return on assets is higher than the cost of debt $(t=-2.90)$ as well as in the case of venturers where the impact of the adoption of proportionate consolidation instead of the equity method in total assets and liabilities is lower than $20 \%$ $(t=2.84)$. Contrary to predictions, the percentage of venturers reporting interests in JCEs by proportionate consolidation is statistically higher in the group of venturers whose leverage is above industry median $(t=2.29)$. A possible explanation for this result is that the group of Link Ventures has a significant number of venturers whose leverage is above the industry median but, as they have a return on assets higher than the cost of debt, they are more likely to report interests in JCEs by proportionate consolidation rather than the equity method. For these venturers, a good proxy for the proximity of covenant limits is not a high leverage but a cost of debt higher than the return on assets. This explanation is in accordance with the discussion on the accounting-based covenants in private debt provided in Section 3. In order to confirm this, we perform a logistic regression of the REPORTING METHOD on the variables LEV_Position and ROAversusCD together and separately. The results show that the inclusion of the variable ROAversusCD makes the LEV_Position statistically insignificant, thus confirming the above explanation.

Table 2 (Panel 2) presents the empirical results for the continuous variables. It shows the mean and the median for the variables LEV, ROA and Assets. It also shows the results for the non-parametric Mann-Whitney test in the case of ROA and for the t-test in the cases of LEV and Assets. The Mann-Whitney test is used when the normality assumption is rejected. For each variable, the difference in means or medians is not statistically significant for all the three cases considered.

Table 3 provides details about the distribution of the venturers' choice across industries. Venturers reporting interests in JCEs using either the equity method or proportionate consolidation are found in each industry although the former 
predominates in all cases. The results of the test for the difference of proportions show that the percentage of venturers reporting interests in JCEs by proportionate consolidation in each industry is not statistically different from the percentages in the other industries. For the group of Scale Venturers, the results are similar to those of All venturers. For the group of Link Venturers, there are three industries where proportionate consolidation is the predominant method. However, the differences of proportions are also statistically insignificant.

Based on the univariate comparisons, we can infer the following. First, the univariate comparisons support our prediction that Link venturers are more likely to report interests in JCEs by proportionate consolidation when compared with the equity method. Second, the univariate comparisons provide some support to the debt-covenant costs hypothesis and to the monitoring costs hypothesis, but only for the group of Link Venturers. In this case, the percentage of venturers that reports interests in JCEs by proportionate consolidation is statistically lower both for those venturers whose ROA is lower than the cost of debt and for those venturers where the impact of the adoption of proportionate consolidation instead of the equity method in total assets or total liabilities is higher that $20 \%$.

As the univariate procedures reported in Tables 2 and 3 can be a weak test to justify the accounting choice detailed in Section 3 (because they are not mutually exclusive and may in fact be reinforced), we also estimated several logistic regression models (with the same dependent variable but with different independent variables combinations) in order to confirm the above conclusions. This econometric analysis enables conclusions to be drawn about the interrelations between different variables considered above and their impact on the probability of a venturer reporting interests in JCEs by proportionate consolidation instead of the equity method.

\subsection{Logistic Regressions}

To obtain more powerful statistical support, we incorporated the variables TYPE, LEV, LEV_Position, LEV $\times$ LEV_Position, ROA, ROA_Position, Assets, Assets_Position, ROAversusCD and Guarantees into several binary logistic regression models. Table 4 reports the parameter estimates from the logistic regressions where the dependent variable (REPORTING METHOD) assumes the values 0 or 1 if the decision is to report interests in JCEs by the equity method or by proportionate consolidation, respectively. The regression in column $\mathrm{C} 1$ includes all the covariates, considering the interaction effect between the variables LEV and LEV_Position ${ }^{19}$ instead of these two variables separately as they are both statistically insignificant in this case; Columns C2-C5 drops individually from C1 the covariates with $p$-value lower than 0.1 to check if there are interaction effects within the explanatory variables in the probability of reporting interests in JCEs by proportionate consolidation instead of the equity method. The regressions in columns $\mathrm{C} 6-\mathrm{C} 10$ include those covariates that are statistically significant when considered separately or in combination with the variable TYPE. 


(1)

\begin{tabular}{|c|c|c|c|c|c|c|c|c|c|c|c|c|c|c|c|}
\hline & \multicolumn{5}{|c|}{ All Venturers } & \multicolumn{5}{|c|}{$\mathrm{TYPE}=0$} & \multicolumn{5}{|c|}{$\mathrm{TYPE}=1$} \\
\hline & \multicolumn{2}{|c|}{ EM } & \multicolumn{2}{|c|}{$\mathrm{PC}$} & \multirow[t]{2}{*}{ Total } & \multicolumn{2}{|c|}{ EM } & \multicolumn{2}{|c|}{$\mathrm{PC}$} & \multirow[t]{2}{*}{ Total } & \multicolumn{2}{|c|}{ EM } & \multicolumn{2}{|c|}{$\mathrm{PC}$} & \multirow[b]{2}{*}{ Total } \\
\hline & $n$ & $\%$ & $n$ & $\%$ & & $n$ & $\%$ & $n$ & $\%$ & & $n$ & $\%$ & $\mathrm{n}$ & $\%$ & \\
\hline \multicolumn{16}{|l|}{ Frequencies } \\
\hline Mining & 21 & $84 \%$ & 4 & $16 \%$ & 25 & 14 & $88 \%$ & 2 & $12 \%$ & 16 & 7 & $78 \%$ & 2 & $22 \%$ & 9 \\
\hline Construction & 16 & $76 \%$ & 5 & $24 \%$ & 21 & 15 & $83 \%$ & 3 & $17 \%$ & 18 & 1 & $33 \%$ & 2 & $67 \%$ & 3 \\
\hline Manufacturing & 13 & $81 \%$ & 3 & $19 \%$ & 16 & 11 & $100 \%$ & 0 & $0 \%$ & 11 & 2 & $40 \%$ & 3 & $60 \%$ & 5 \\
\hline Utilities & 21 & $75 \%$ & 7 & $25 \%$ & 28 & 18 & $95 \%$ & 1 & $5 \%$ & 19 & 3 & $33 \%$ & 6 & $67 \%$ & 9 \\
\hline Retail Trade & 12 & $92 \%$ & 1 & $8 \%$ & 13 & 8 & $100 \%$ & 0 & $0 \%$ & 8 & 4 & $80 \%$ & 1 & $20 \%$ & 5 \\
\hline Real Estate & 19 & $79 \%$ & 5 & $21 \%$ & 24 & 12 & $100 \%$ & 0 & $0 \%$ & 12 & 7 & $58 \%$ & 5 & $42 \%$ & 12 \\
\hline Services & 23 & $72 \%$ & 9 & $28 \%$ & 32 & 15 & $94 \%$ & 1 & $6 \%$ & 16 & 8 & $50 \%$ & 8 & $50 \%$ & 16 \\
\hline \multicolumn{16}{|l|}{ Comparison test $t^{1}$} \\
\hline Mining & & & & & 0.71 & & & & & -0.94 & & & & & 1.55 \\
\hline Construction & & & & & -0.29 & & & & & $-1.79^{*}$ & & & & & -0.74 \\
\hline Manufacturing & & & & & 0.27 & & & & & 0.96 & & & & & -0.66 \\
\hline Utilities & & & & & -0.51 & & & & & 0.33 & & & & & -1.37 \\
\hline Retail Trade & & & & & 1.26 & & & & & 0.80 & & & & & 1.20 \\
\hline Real Estate & & & & & 0.07 & & & & & 1.01 & & & & & 0.31 \\
\hline Services & & & & & -1.04 & & & & & 0.13 & & & & & -0.39 \\
\hline
\end{tabular}

TYPE $=0$ if the majority of the venturer's JCE are Scale and TYPE $=1$ if the majority of the venturer's JCE are Link.

${ }^{1}$ Test of difference between proportions. ${ }^{* * *},{ }^{* *}$ and ${ }^{*}$ indicate significance at the $0.01,0.05$ and 0.10 levels respectively. 
Table 4. Logistic regression results (All Ventures $=159)$

\begin{tabular}{|c|c|c|c|c|c|c|c|c|c|c|c|}
\hline & Exp. Sign & $\mathrm{C} 1$ & $\mathrm{C} 2$ & $\mathrm{C} 3$ & $\mathrm{C} 4$ & $\mathrm{C} 5$ & C6 & $\mathrm{C} 7$ & $\mathrm{C} 8$ & C9 & $\mathrm{C} 10$ \\
\hline Intercept & & -3.578 & -1.369 & -3.187 & -3.147 & -3.704 & $-2.587^{* * *}$ & $-0.977^{* * *}$ & $-2.276^{* * *}$ & $-3.339^{* * *}$ & $-2.509^{* * *}$ \\
\hline TYPE & + & $3.711^{* * *}$ & & $3.778^{* * *}$ & $3.204^{* * *}$ & $3.291^{* * *}$ & $2.417^{* * *}$ & & $2.456^{* * *}$ & $2.851^{* * *}$ & $2.740^{* * *}$ \\
\hline LEV x LEV_Position & - & $-6.699^{*}$ & $-8.128^{* *}$ & & $-7.100^{*}$ & $-7.858^{* *}$ & & $-7.364^{* *}$ & $-7.165^{* *}$ & & \\
\hline ROA & + & 3.120 & 0.874 & 3.025 & 5.153 & 2.248 & & & & & \\
\hline ROA_Position & + & -1.133 & -0.535 & $-1.136^{*}$ & -0.327 & -0.973 & & & & & \\
\hline Assets & - & 0.196 & 0.066 & 0.022 & 0.258 & 0.305 & & & & & \\
\hline Assets_Position & - & 0.909 & 0.402 & 0.628 & 0.819 & 0.913 & & & & & \\
\hline ROAversusCD & + & $1.860^{* *}$ & 0.626 & $1.885^{* *}$ & & $1.666^{* *}$ & & & & $1.175^{* *}$ & \\
\hline ImpChange & - & $-2.191^{* *}$ & -0.657 & $-2.400^{* *}$ & $-1.983^{* *}$ & & & & & & $-2.070^{* * *}$ \\
\hline Guarantees & + & 0.402 & -0.030 & 0.493 & 0.242 & 0.041 & & & & & \\
\hline Mining & & -0.971 & -0.298 & -0.948 & -0.780 & -1.604 & & & & & \\
\hline Manufacturing & & -0.901 & -0.128 & -0.745 & -0.909 & -1.063 & & & & & \\
\hline Utilities & & -0.740 & 0.175 & -0.818 & -0.492 & -0.549 & & & & & \\
\hline Retail Trade & & -1.508 & -1.375 & -1.590 & -1.651 & -2.213 & & & & & \\
\hline Real Estate & & -0.817 & 0.253 & -1.032 & -1.104 & -0.705 & & & & & \\
\hline Services & & -0.700 & 0.347 & -0.810 & -0.812 & -0.557 & & & & & \\
\hline LR statistic & & $59.749^{* * *}$ & 13.802 & $56.094^{* * *}$ & $53.208^{* * *}$ & $54.173^{* * *}$ & $32.946^{* * *}$ & $6.728^{* * *}$ & $39.394^{* * *}$ & $38.702^{* * *}$ & $42.046^{* * *}$ \\
\hline McFadden $\mathrm{R}^{2}$ & & 0.362 & 0.084 & 0.400 & 0.322 & 0.328 & 0.200 & 0.041 & 0.239 & 0.234 & 0.255 \\
\hline
\end{tabular}

Dependent Variable: REPORTING METHOD $=0$ if the venturer reports interests in JCEs by the equity method; REPORTING METHOD $=1$ if the venturer reports interests in JCEs by proportionate consolidation.

Independent Variables: TYPE $=0$ if the majority of the venturer's JCE are Scale and TYPE $=1$ otherwise; LEV $=$ debt divided by market capitalization;

LEV Position $=0$ if the venturer's leverage is above industry median and LEV Position $=1$ otherwise; ROA $=$ earnings before interests on debt divided by the previous year's total assets; ROA_Position $=0$ if the venturer's return on assets is below industry median and ROA_Position $=1$ otherwise; Assets $=$ total assets Assets_Position $=0$ if the venturer's total assets is above industry median and Assets_Position $=1$ otherwise; ROAversusCD $=0$ if the venturer's return on assets is lower than cost of debt and ROAversusCD $=1$ otherwise; ImpChange $=0$ if the adoption of proportionate consolidation instead of the equity method has or would have a less than $20 \%$ impact on the venturer's assets and liabilities and ImpChange $=1$ otherwise; Guarantees $=0$ if the venturer does not provide guarantees to JCES' debt and Guarantees $=1$ otherwise.

***, ${ }^{* *}$ and $*$ indicate significance at the $0.01,0.05$ and 0.10 levels respectively. 


\section{Type of JCEs hypothesis}

There is strong support for the type of JCE hypothesis. As can be seen in Table 4, the estimated coefficient on the TYPE is always very reliable and positive as predicted, regardless of the other covariates included. Based on the absolute value and its corresponding sign, we can conclude that the estimated probability of reporting interests in JCEs by proportionate consolidation is statistically higher for the Link Venturers even if the estimated coefficient cannot be considered the TYPE marginal effect. The estimated coefficient for TYPE always has the lowest probability associated with the significance t-test result ( $p$-value $=$ 0.000). Thus, we conclude that TYPE is the most relevant covariate to explain the probability of a venturer reporting interests in JCEs by proportionate consolidation instead of the equity method.

As the exponential of each coefficient estimate is the odds-ratio for the associated covariate in a logistic regression and it measures the change in the odds of the dependent variable taking the higher of its two values when the covariate increases by 1 , we also computed the exponential for all the coefficient estimates in column C1 (Table 5), in accordance with Hand and Skantz (1998). The exponential is substantially higher for TYPE estimated coefficient $($ Exp $=40.902)$, confirming the relative importance of this covariate when compared with the others (although the relative importance comparison based on exponentials is not straightforward due to the difference in the covariates' units of measure).

\section{Alternative explanations of the accounting choice}

As can be seen in Table 4, the coefficient estimate for LEV $\times$ LEV_Position is negative (C1: -6.699; C7: -7.364) and statistically significant. Thus, we can conclude that the leverage has a negative impact on the decision to report interests in JCEs by proportionate consolidation, but only for those venturers whose leverage is below the industry median. There is also support for the expectation of a negative relationship between a venturer having a ROA lower than the cost of debt and the choice of reporting interests in JCEs by proportionate consolidation, but only for the group of Link Venturers. Table 4 shows that the estimated coefficient for the ROAversusCD is statistically significant and positive (C1: 1.860), but only when the variable TYPE is also included in the regression. Finally, the results also support the expectation of a negative relationship between a strong impact on the venturer's assets or liabilities resulting from the adoption of proportionate consolidation and the venturer's decision to apply this method, but once again only for the group of Link venturers. These results are not affected by the correlation among the explanatory variables. In order to check this, we computed the VIF (Variance Inflation Factor) for each variable included in the complete logistic regression model. Untabulated results show that all the statistics are well below the rule-of-thumb 10 . The correlation among the explanatory variables is therefore very weak and does not affect the estimation results. 
Table 5. Relative importance of different covariates in the logistic regression (All venturers)

\begin{tabular}{lcr}
\hline & Coefficient estimates (C.E.) & Exp (C.E.) \\
\hline Intercept & -3.578 & 0.028 \\
TYPE & 3.711 & 40.902 \\
LEV $\times$ LEV_Position & -6.699 & 0.001 \\
ROA & 3.120 & 22.653 \\
ROA_Position & -1.133 & 0.322 \\
Assets & 0.196 & 1.216 \\
Assets_Position & 0.909 & 2.483 \\
ROAversusCD & 1.860 & 6.421 \\
ImpChange & -2.191 & 0.112 \\
Guarantees & 0.402 & 1.495 \\
Mining & -0.971 & 0.379 \\
Manufacturing & -0.901 & 0.406 \\
Utilities & -0.740 & 0.477 \\
Retail Trade & -1.508 & 0.221 \\
Real Estate & -0.817 & 0.442 \\
Services & -0.700 & 0.497 \\
\hline
\end{tabular}

Dependent Variable: REPORTING METHOD $=0$ if the venturer reports interests in JCEs by the equity method; REPORTING METHOD $=1$ if the venturer reports interests in JCEs by proportionate consolidation.

Independent Variables: TYPE $=0$ if the majority of the venturer's JCE are Scale and TYPE $=1$ otherwise; LEV = debt divided by market capitalization; LEV_Position $=0$ if the venturer's leverage is above industry median and LEV_Position $=1$ otherwise; ROA $=$ earnings before interests on debt divided by the previous year's total assets; ROA_Position $=0$ if the venturer's return on assets is below industry median and ROA_Position $=1$ otherwise; Assets $=$ total assets; Assets_Position $=0$ if the venturer's total assets is above industry median and Assets_Position $=1$ otherwise; ROAversusCD $=0$ if the venturer's return on assets is lower than cost of debt and ROAversusCD $=1$ otherwise; ImpChange $=0$ if the adoption of proportionate consolidation instead of the equity method has or would have a less than $20 \%$ impact on the venturer's assets and liabilities and ImpChange $=1$ otherwise; Guarantees $=0$ if the venturer does not provide guarantees to JCES' debt and Guarantees $=1$ otherwise.

A separate estimation of the logistic regressions for each of the groups of venturers identified based on the type of JCE: Scale Venturers (TYPE $=0$ ) and Link Venturers $(\mathrm{TYPE}=1)$ was also performed. Table 6 reports the findings from these two binary logistic regressions, which corroborate the results presented in Table 4. As can be seen, the estimated coefficients on the LEV $\times$ LEV_Position, on the ROAversusCD and on the ImpChange are statistically significant and have the predicted sign but only for the group of Link Venturers. This means that a leverage lower but near the industry median, a return on assets lower than the cost of debt or a large change in the venturer's assets or liabilities negatively affect the decision to report interests in JCEs by proportionate consolidation but only for the group of venturers with economic incentives to apply this method, i.e. the Link venturers. The first two variables $(\mathrm{LEV} \times \mathrm{LEV}$ _Position and ROAversus CD) are proxies for debt covenant costs while the variable ImpChange is used as a proxy for monitoring costs. Thus, the regression 
Table 6. Logistic regressions results (Scale venturers: $n=100$ and Link venturers: $n=59$ )

\begin{tabular}{|c|c|c|c|c|c|c|c|c|c|}
\hline & \multirow[b]{2}{*}{ Exp. Sign } & \multirow{2}{*}{$\frac{\text { TYPEJCE }=0}{\mathrm{C} 1}$} & \multicolumn{7}{|c|}{ TYPEJCE $=1$} \\
\hline & & & $\mathrm{C} 1$ & $\mathrm{C} 2$ & $\mathrm{C} 3$ & $\mathrm{C} 4$ & $\mathrm{C} 5$ & C6 & $\mathrm{C} 7$ \\
\hline Intercept & & -5.540 & -1.006 & 0.634 & -0.692 & -1.021 & 0.313 & $-0.051^{* *}$ & 0.223 \\
\hline LEV $\times$ LEV_Position & - & -0.337 & $-17.041^{* *}$ & & $-14.755^{* *}$ & $-14.186^{* *}$ & $-11.138^{* *}$ & & \\
\hline ROA & + & 2.715 & 1.778 & 1.766 & 4.865 & 0.486 & & & \\
\hline ROA_Position & + & -1.379 & -1.878 & -1.463 & 0.026 & -1.193 & & & \\
\hline Assets & - & 0.884 & -0.290 & -0.464 & 0.000 & -0.079 & & & \\
\hline Assets_Position & - & 1.634 & 2.025 & 0.676 & 1.088 & 1.490 & & & \\
\hline ROAversusCD & + & 0.775 & $5.571^{* *}$ & $4.408^{* * *}$ & & $3.339^{* *}$ & & $1.723^{* * *}$ & \\
\hline ImpChange & - & -18.412 & $-3.932^{* *}$ & $-3.013^{* *}$ & -1.718 & & & & $-2.015^{* *}$ \\
\hline Guarantees & + & -0.083 & 2.896 & 1.879 & 0.758 & 1.067 & & & \\
\hline Mining & & 0.205 & -2.141 & -2.266 & -0.482 & -2.151 & & & \\
\hline Manufacturing & & -18.866 & 0.128 & 0.082 & 0.380 & -0.163 & & & \\
\hline Utilities & & -1.226 & 1.499 & 0.357 & 1.753 & 1.574 & & & \\
\hline Retail Trade & & -19.348 & 2.479 & 0.430 & 0.273 & -0.177 & & & \\
\hline Real Estate & & -18.897 & 2.392 & 0.850 & 0.700 & 1.647 & & & \\
\hline Services & & -0.421 & 1.646 & 0.363 & 0.575 & 1.014 & & & \\
\hline LR statistic & & 10.441 & $33.795^{* * *}$ & $26.245^{* *}$ & $21.487^{*}$ & $27.637^{* * *}$ & $8.986^{* * *}$ & $7.754^{* * *}$ & $8.057^{* * *}$ \\
\hline McFadden $\mathrm{R}^{2}$ & & 0.206 & 0.415 & 0.323 & 0.264 & 0.340 & 0.110 & 0.095 & 0.099 \\
\hline
\end{tabular}

Dependent Variable: REPORTING METHOD $=0$ if the venturer reports interests in JCEs by the equity method; REPORTING METHOD $=1$ if the venturer reports interests in JCEs by proportionate consolidation.

Independent Variables: LEV = debt divided by market capitalization; LEV_Position $=0$ if the venturer's leverage is above industry median and LEV_Position $=1$ otherwise; ROA = earnings before interests on debt divided by the previous year's total assets; ROA_Position $=0$ if the venturer's return on assets is below industry median and ROA Position $=1$ otherwise; Assets $=$ total assets; Assets_Position $=0$ if the venturer's total assets is above industry median and Assets Position $=1$ otherwise; ROAversusCD $=0$ if the venturer's return on assets is lower than cost of debt and ROAversusCD $=1$ otherwise; ImpChange $=0$ if the adoption of proportionate consolidation instead of the equity method has or would have a less than $20 \%$ impact on the venturer's assets and liabilities and ImpChange $=1$ otherwise; Guarantees $=0$ if the venturer does not provide guarantees to JCES' debt and Guarantees $=1$ otherwise

$* * *, * *$ and ${ }^{*}$ indicate significance at the $0.01,0.05$ and 0.10 levels respectively. 
results also provide additional evidence on the role of these costs in the choice between two alternative reporting methods.

Overall, our findings provide evidence that Link venturers are more likely to apply proportionate consolidation, unless their leverage is lower than but approximate to the industry median, their return on assets is lower than the cost of debt or the change to proportionate consolidation would have a significant impact on the venturer's total assets or total liabilities. Therefore, the findings support our prediction that the type of JCE plays an important role in the management decision to report interests in JCEs using the equity method or proportionate consolidation; at the same time, however, additional evidence is provided that supports the importance of debt covenant costs and monitoring costs in the choice between these two alternative reporting methods.

\section{Summary and Conclusions}

There is no international consensus on the appropriate reporting method for interests in JCEs. Policy makers are conscious of the need to find a consensual solution on this issue. The IASB is engaged in a joint convergence project with the FASB in order to find a consensual solution and remove the option of accounting for interests in JCEs using either the equity method or proportionate consolidation from IAS 31 (2003).

Progress on this issue has been hampered by a gap in the accounting choice literature on the determinants of the choice to report interests in JCEs by the equity method or by proportionate consolidation. The largely unaddressed question bearing on this issue is the extent to which management choices are based on their insights into the underlying economics of their JCEs. This paper contributes to the accounting choice literature by answering this question in a unique setting where management has discretion to apply one of the reporting methods for interests in JCEs.

The results of this study support our prediction that the type of JCE plays an important role in the management's choice to report interests in JCEs by the equity method or by proportionate consolidation. However, the results also provide empirical evidence supporting the importance of debt covenant costs and monitoring costs in the choice between alternative reporting methods.

The analysis of the consequences of the accounting choice between alternative reporting methods for interests in JCEs is a promising avenue for future research. Recent studies have already provided useful evidence on the consequences of accounting choice in other contexts, like the capitalization of R\&D expenditures (Oswald and Zarowin, 2007) and the accounting for business combinations (Martínez-Jerez, 2008). This kind of analysis in the context of JCEs could provide additional insights potentially useful to the international debate on joint ventures accounting. 


\section{Acknowledgements}

We are grateful to the participants at the 2006 European Accounting Association Congress (Dublin) and at the 2009 Mid-Year Conference of the American Accounting Association (International Section, Florida), and to two anonymous referees for their helpful comments and suggestions. We are also grateful to Professor Salvador Carmona and to our colleagues Ana Isabel Morais from ISCTE - IUL Business School, José António Moreira from Oporto University and Sebahattin Demirkan from Binghampton University for their help and useful suggestions to improve this paper.

\section{Notes}

${ }^{1}$ Whittred (1987) documents a relationship between the adoption of consolidated reporting in Australia and the number and type of subsidiaries, as well as the management's share of a firm's equity and the presence of inter-company guarantees.

${ }^{2}$ Mian and Smith (1990) analyze the incentives to report the performance of financial subsidiaries on a consolidated or unconsolidated basis prior to the Financial Accounting Standards Board Statement 94. This study provides evidence that the greater the operating, financial and informational interdependencies between parent and subsidiary, the more US parents are likely to choose to report the operations of a financial subsidiary on a consolidated basis.

${ }^{3}$ Whittred and Zimmer (1994) use the case of accounting for unincorporated joint ventures in the Australian extractive industries to demonstrate how accounting methods can be determined by the firm's type of assets (assets in the exploration sector versus assets in the development/ production sector) and the manner in which they are financed (on a 'non-recourse' basis versus on a 'with-recourse' basis).

${ }^{4}$ The venturer's share of JCEs' assets, liabilities, revenue and expenses can be reported in the venturer's financial statements as separate line items (Format 1) or they can be combined line by line with the similar items from the venturer (Format 2).

${ }^{5}$ This is true in the absence of inter-company transactions.

${ }^{6}$ This is usually a negative impact.

${ }^{7}$ In the Balance Sheet, interests in JCEs presented as an asset should be desegregated in two items: the venturer's share of JCEs' assets less the venturer's share of JCEs' liabilities. In the Income Statement, the venturer's share of JCEs' revenue from sales should be presented as an amount deducted from total revenue from sales in order to present just the venturer's revenue from sales.

${ }^{8}$ According to IAS 31, Interests in Joint Ventures (IASB, 2003), those ventures applying the line-by-line reporting format for proportionate consolidation or the equity method shall disclose the aggregate amount of each of current assets, long-term assets, current liabilities, long-term liabilities, income and expenses related to its interests in joint ventures.

${ }^{9}$ For example, the market for crude is a failing market. Oil refining is a capital-intensive flow process, requiring constant throughput. As storing crude oil is costly, refineries are custombuilt to handle a particular type of crude. The market for this raw material tends therefore to be thin, exposing parties to opportunistic behaviour. For this reason, oil refiners have found it necessary to integrate backward into crude exploration and production instead of writing long-term contracts with independent crude producers (Hennart, 1988).

${ }^{10}$ These Comment Letters are available at www.iasb.org/current + projects/IASB + projects/ joint + ventures.htm

${ }^{11}$ Where debt is secured, the scope for debt holder and shareholder conflict is reduced since the lender's claim over specific assets limits the likelihood of asset substitution and claim dissolution. 
${ }^{12}$ Mather and Peirson (2006) found similar results in relation to most covenants used in Australian private debt.

${ }^{13}$ Dichev and Skinner (2002) demonstrate empirically that firms that violate debt covenants enclosed in private debt agreements tend to be more highly levered and less profitable (lower ROA and lower coverage ratio) than firms that do not violate such covenants.

${ }^{14}$ The IAS 31, Interests in Joint Ventures (IASB, 2003), requires venturers to disclose in the Notes the aggregate amount of each of current assets, long-term assets, current liabilities, long-term liabilities, income and expenses related to its interests in JCEs. However, this information does not allow users to compute some ratios, like the return on assets, as if the venturer would report interests in JCEs by the alternative method.

${ }^{15}$ Almost all the firms listed in the London Stock Exchange belonging to the FTSE All Shares applied IFRS for the first time in the year of compulsory adoption. We found two early adopter firms with interests in JCEs. They are both foreign firms and their interests in JCEs are reported by proportionate consolidation. The inclusion of these firms would not be relevant for the purpose of our study.

${ }^{16}$ In the exceptional cases where the information is not available in the Thomson Worldscope Database, we use information hand-collected from the venturers' annual consolidated financial statements presented in their website.

${ }^{17}$ A Scale and a Link Venturer are ventures where the majority of JCEs are, respectively, Scale and Link.

${ }^{18}$ The UK GAAP require venturers to report interests in JCEs as an asset (equity method) and to provide additional information about the venturer's share of JCEs' assets and liabilities. This information is always presented by the venturers and enables the computation of pro forma total assets and total liabilities as if JCEs were reported by proportionate consolidation instead of the equity method.

${ }^{19}$ Ali and Kumar (1994) suggest the inclusion of interactions in order to enhance the ability to explain accounting choice decisions.

\section{References}

Accounting Principles Board (1971) APB Opinion 18: The Equity Method of Accounting for Investments in Common Stock.

Accounting Standards Board (1997) FRS 9: Associates and Joint Ventures.

Ali, A. and Kumar, K. (1994) The magnitudes of financial statements effects and accounting choice: the case of the adoption of SFAS 87', Journal of Accounting and Economics, 18, pp. 89-114.

Australian Accounting Standards Board (2004) Australian Accounting Standard 131, Interests in Joint Ventures.

Balakrishnan, S. and Koza, M. (1993) Information asymmetry, adverse selection, and joint ventures: theory and evidence, Journal of Economic Behaviour and Organization, 20, pp. 99-117.

Bauman, M. (2003) The impact and valuation of off-balance-sheet activities concealed by equity method accounting, Accounting Horizons, 17, pp. 303-314.

Bauman, M. (2007) Proportionate consolidation versus the equity method: additional evidence on the association with bond ratings, International Review of Financial Analysis, 16, pp. 496-507.

Canadian Institute of Chartered Accountants (1994) CICA Handbook.

Chen, S. and Hennart, J. (2004) A hostage theory of joint ventures: why do Japanese investors choose partial over full acquisitions to enter the United States? Journal of Business Research, 57, pp. 1126-1134.

Citron, D. (1995) The incidence of accounting-based covenants in U.K. public debt contracts: an empirical analysis, Accounting and Business Research, 25, pp. 139-150.

D'Souza, J., Jacob, J. and Ramesh, K. (2001) The use of flexibility to reduce labour renegotiation costs and manage earnings, Journal of Accounting and Economics, 30, pp. 187-208. 
Dichev, I. and Skinner, D. (2002) Large-sample evidence on the debt covenant hypothesis, Journal of Accounting Research, 40, pp. 1091-1123.

Duke, J. and Hunt, H. (1990) An empirical examination of debt covenants restrictions and accountingrelated debt proxies, Journal of Accounting and Economics, 12, pp. 45-65.

Fields, T., Lys, T. and Vincent, L. (2001) Empirical research on accounting choice, Journal of Accounting and Economics, 31, pp. 255-307.

Georgiou, G. (2005) Investigating corporate management lobbying in the U.K.. accounting standardsetting process: a multi-issue/multi-period approach, Abacus, 41, pp. 323-347.

Graham, R., King, R. and Morril, C. (2003) Decision usefulness of alternative joint venture reporting methods, Accounting Horizons, 17, pp. 123-137.

Hand, J. and Skantz, T. (1998) The economic determinants of accounting choice: the unique case of equity carve-outs under SAB 51, Journal of Accounting and Economics, 24, pp. 175-203.

Hennart, J. (1988) A transaction costs theory of equity joint ventures, Strategic Management Journal, 9(4), pp. 361-374.

Hennart, J. (1991) The transaction costs theory of joint ventures: an empirical study of Japanese subsidiaries in the United States, Management Science, 37(4), pp. 483-497.

Hennart, J. and Reddy, S. (1997) The choice between mergers/acquisitions and joint ventures: the case of Japanese investors in the United States, Strategic Management Journal, 18, pp. 1-12.

International Accounting Standards Board (2003) IAS 31: Interests in Joint Ventures.

Jeter, D., Chaney, P. and Daley, M. (2008) Joint accounting choices: an examination of firms' adoption strategies for SFAS no 106 and SFAS no 109, Review of Quantitative Finance and Accounting, 30, pp. 153-185.

Knoeber, C. and McKee, A. (1991) Accounting choice: the role of monitoring costs, Managerial and Decision Economics, 12, pp. 353-360.

Kothavala, K. (2003) Proportional consolidation versus the equity method: a risk measurement perspective on reporting interests in joint ventures, Journal of Accounting and Public Policy, 22, pp. 517-538.

Lim, C., Yeo, C. and Liu, C. (2003) Information asymmetry and accounting disclosures for joint ventures, International Journal of Accounting, 38, pp. 23-39.

Lindahl, F. (1989) Dynamic analysis of inventory accounting choice, Journal of Accounting Research, 27, pp. 201-226.

Maines, L., McDaniel, L. and Harris, M. (1997) Implications of proposed segment reporting standards for financial analysts' investment judgments, Journal of Accounting Research, 35, pp. 1-24.

Martínez-Jerez, F. (2008) Governance and merger accounting: evidence from stock price reactions to purchase versus pooling, European Accounting Review, 17, pp. 5-35.

Mather, P. and Peirson, G. (2006) Financial covenants in the markets for public and private debt, Accounting and Finance, 46, pp. 285-307.

Mian, S. and Smith, C. (1990) Incentives for unconsolidated financial reporting, Journal of Accounting and Economics, 12, pp. 141-171.

Moir, L. and Sudarsanam, S. (2007) Determinants of financial covenants and pricing of debt in private debt contracts: the U.K. evidence, Accounting and Business Research, 37, pp. 151-166.

Nichols, N. and Street, D. (2007) The relation between competition and business segment reporting decisions under the management approach of IAS 14 revised, Journal of International Accounting, Auditing and Taxation, 16, pp. 51-68.

O'Hanlon, J. and Taylor, P. (2007) The value relevance of disclosures of liabilities of equityaccounted investees: UK evidence, Accounting and Business Research, 37, pp. 267-284.

Oswald, D. and Zarowin, P. (2007) Capitalization of R\&D and the informativeness of stock prices, European Accounting Review, 16, pp. 703-726.

Press, E. and Weintrop, J. (1990) Accounting-based constrains in public and private debt agreements: the association with leverage and impact on accounting choice, Journal of Accounting and Economics, 12, pp. 65-97. 
Smith, C. (1993) A perspective on accounting-based debt covenant violations, Accounting Review, 68, pp. 289-303.

Soonawalla, K. (2005) Accounting for joint ventures and associates in Canada, U.K., and US: do US rules hide information? Journal of Business Finance and Accounting, 3-4, pp. 395-417.

Stoltzfus, R. and Epps, R. (2005) An empirical study of the value-relevance of using proportionate consolidation accounting for investments in joint ventures, Accounting Forum, 29, pp. 169-190.

Whittred, G. (1987) The derived demand for consolidated financial reporting, Journal of Accounting and Economics, 9, pp. 259-285.

Whittred, G. and Zimmer, I. (1994) Contracting costs determinants of GAAP for joint ventures in an unregulated environment, Journal of Accounting and Economics, 17, pp. 95-111.

Wyatt, A. (2005) Accounting recognition of intangible assets: theory and evidence on economic determinants, The Accounting Review, 80, pp. 967-1003. 